\title{
Investigation of ammonia removal from polluted waters by Clinoptilolite zeolite
}

\author{
${ }^{I^{*}}$ A. R. Rahmani, ${ }^{2}$ A. H. Mahvi, ${ }^{2}$ A. R. Mesdaghinia and ${ }^{2}$ S. Nasseri \\ ${ }^{I}$ Department of Environmental Health, School of Public Health, Hamadan University of Medical Sciences, Hamadan, Iran \\ ${ }^{2}$ Department of Environmental Health Engineering, School of Public Health and Institute of Health Research Center, Tehran \\ University of Medical Sciences, Tehran, Iran
}

\begin{abstract}
Ammonia nitrogen compounds in the wastewaters and effluents have harmful effects on water resources. Ion exchange with zeolites is a separation process for ammonia removal from effluents. The objective of this research was to study the efficiency of an ammonia removal and the factor affecting to this process. The Clinoptilolite was obtained from Semnan mines at the north part of Iran. The samples were grounded and sieved based on the U.S. standard mesh number 20,30, 40 and conditioned by ammonia sulfate and sodium chloride solutions. The characteristics of samples for ammonia removal and the selectivity sequence for adsorbing interfering cations were then determined. Results shown that the average ion exchange capacity of zeolite in batch and continuous systems were 6.65-16 and 16.31-19.5 $\mathrm{mg} \mathrm{NH}_{4}{ }^{+} / \mathrm{g}$ zeolite weight, respectively. In study on the zeolite for selective cations showed the ranking of $\mathrm{K}^{+}, \mathrm{NH}_{4}{ }^{+}, \mathrm{Na}^{+}, \mathrm{Ca}^{2+}$ and $\mathrm{Mg}^{2+}$ respectively. Results indicated that high level of regeneration (95-98\%) might be achieved with $\mathrm{NaCl}$ solution. Based on the results, Clinoptilolite may be effective applied in wastewater treatment, both from technical and economical aspects.
\end{abstract}

Key words: Clinoptilolite, zeolite, wastewater treatment, ammonia, ion exchange

*Corresponding Author, E-mail: rahmani@umsha.ac.ir

\section{Introduction}

Ammonia nitrogen discharges from municipal, industrial and agricultural wastewater sites, which subsequently mixes into water resources. Some of deleterious effects include accelerated eutrophication of lake, dissolved oxygen depletion in receiving waters and fish toxicity (EPA, 1975). The maximum limit of ammonia set by the European Association for drinking water is approximately $0.5 \mathrm{mg} \mathrm{l}^{-1}$ and also a guide level is given as $0.05 \mathrm{mg} \mathrm{l}^{-1}$ (AWWA, 1990 and Gaspard, et al., 1983). The raw water with high ammonia concentration must therefore be treated before it reaches the consumer and also the wastewater discharge into the receiving water. The most widely used methods for removing ammonia from wastewater are air stripping, ion exchange, breakpoint chlorination and biological nitrificationdenitrification (Metcalf and Eddy, 2003). Ion exchange has been demonstrated to be competitive with other methods both in terms of performance and cost (Mercer, et al., 1970 and Culp, et al., 1978). Clinoptilolite is one of the natural zeolites used to remove the cations and ammonia ions from aqueous solutions (Mercer, et al., 1970; Koon and Kaufman, 1975 and Schoman, 1986). In addition to have a greater affinity for ammonia ions than other exchange media, it is relatively inexpensive when compared to synthetic sorbents employed. Several authors have investigated ammonia removal form polluted water by natural zeolite. Ames (1967) and Mercer (1970) suggested that the use of Clinoptilolite for removal of $\mathrm{NH}_{4}{ }^{+}$from wastewater. In these studies sedimentation effluent with 10 to 19 $\mathrm{mg} / \mathrm{l} \mathrm{NH}_{4}{ }^{+}$treated and efficiency of process was obtained 93 to $98 \%$. Koon and Kaufman (1975) were concerned with ammonia removal from municipal wastewater by Clinoptilolite. The pilot study by Liberti (1981) on ammonia removal by Clinoptilolite showed that the ion selectivity by zeolite for ammonia. Gaspard, et al., (1983) examined the ammonia removal characteristics from drinking water by Clinoptilolite. Ershov (1984) studied the ammonia removal in laboratory and semi industrial scale. In these studies the $10 \% \mathrm{NaCl}$ solution was used for regeneration. Schoeman 
(1986) evaluated $\mathrm{NH}_{3}-\mathrm{N}$ removal from an underground mine water by South African Clinoptilolite and compared it with Hector Clinoptilolite from the USA. Haralambous, et al., (1992) compared natural and synthetic zeolites for ammonia removal from aqueous solution.

In the aqueous solution, ammonia may exist in either the nonionized form $\left(\mathrm{NH}_{3}\right)$ and/or ionized form $\left(\mathrm{NH}_{4}{ }^{+}\right)$depending on the $\mathrm{pH}$ and temperature. The ion-exchange process can remove only the ionized one. The equilibriumexchange capacity remains constantly up to $\mathrm{pH}$ 7. The $\mathrm{pH}$ of the aqueous solution must be at/or below 7 for optimum ion-exchange operation. During the ion-exchange process, the $\mathrm{Na}^{+}$ion is replaced by the $\mathrm{NH}_{4}{ }^{+}$ion, and hence the $\mathrm{Na}^{+}$ion concentration increases in the liquid phase during the ion-exchange processes. When the ion-exchanger reaches breakthrough, the up flow or down flow regeneration method is applied. Gaspard, et al., (1983) reported that the up flow regeneration is more attractive than down flow regeneration. Thus the first is ion exchange and as soon as Clinoptilolite containing a large amount of ammonia ions is in contact with salt solution and ion exchange takes place according to equation 1:

$$
\mathrm{Z}-\mathrm{NH}_{4}{ }^{+}+\mathrm{Na}^{+} \longleftrightarrow \mathrm{Z}-\mathrm{Na}^{+}+\mathrm{NH}_{4}^{+}
$$

The ammonia ion-exchange capacity varies depending on the presence of another cations in the aqueous phase and initial ammonia concentration (Gaspard, et al., 1983 and Singh and Prasad, 1997).

The present work considers ammonia removal by a natural ion-exchange resin. This investigation concentrates on defining various operational parameters necessary to remove ammonia through ion exchange by using the Clinoptilolite, zeolite.

The main objective of this paper is to evaluate the characteristics of Semnan Clinoptilolite for removing ammonia ions from aqueous solutions under varying conditions.

\section{Materials and Methods}

In this study the Clinoptilolite in rock form was supplied from Semnan mines in the north part of Iran during 2000-2001. The experiments were conducted in two phases with investigations batch sorption and column studies. The chemical properties of Semnan Clinoptilolite used in this study were studied by Kazemian (1993), are given in Table 1.

Table 1: Chemical analysis of Semnan Clinoptilolite based on XRD*

\begin{tabular}{|lc|}
\hline Constituent & \% By weight \\
\hline $\mathrm{SiO}_{2}$ & 69.53 \\
\hline $\mathrm{CaO}$ & 3.67 \\
\hline $\mathrm{K}_{2} \mathrm{O}$ & 2.77 \\
\hline $\mathrm{Al}_{2} \mathrm{O}_{3}$ & 7.75 \\
\hline $\mathrm{Na}_{2} \mathrm{O}$ & 0.63 \\
\hline $\mathrm{Fe}_{2} \mathrm{O}_{3}$ & 1.41 \\
\hline $\mathrm{TiO}_{2}$ & 0.19 \\
\hline $\mathrm{LOI}$ & 12.94 \\
\hline Total & 99.37 \\
\hline
\end{tabular}

* X Ray Diffraction

All analysis was made according to the Standard Methods (1992). Ammonia was then determined by the Nessler method. Ammonia chloride stoke solution was prepared by dissolving $1 \mathrm{~g} \mathrm{NH}_{4} \mathrm{Cl}$ in 1 liter of demonized water. For preparation of synthetic samples the appropriate amounts of ammonia chloride stoke were added to distilled water to give the desired ammonia concentration.

The collected Clinoptilolite samples were grounded and sieved and the fractions between U.S. standard mesh numbers 20, 30 and 40 $(0.84,0.589$ and $0.42 \mathrm{~mm})$ were used for the study. The zeolite samples after being washed for removal of fine, conditioned by $0.25-\mathrm{M}$ ammonia sulfate and $1 \mathrm{M}$ sodium chloride respectively. The samples were then rinsed and stored dry. The characteristics of the zeolite for ammonia exchange were determined in two batch and continuous systems.

\section{Batch studies}

1) In the first phase of runs, $500 \mathrm{ml}$ of ammonia chloride solution with $1000 \mathrm{mg} / \mathrm{l}$ strength were conducted in separate stages with different weights and sizes of conditioned zeolite samples. After mixing for 48 hours ammonia remained in solution was measured with Nessler method. The cation exchange capacities for ammonia were determined by dividing the amount of ammonia removal by the mass of zeolite in the flask.

2) In the second phase of runs, batch sorption isotherms for the removal of ammonia 
were investigated. In $1000 \mathrm{ml}$ conical flasks at $20^{\circ} \mathrm{C}$. Weighed amounts (30 g with mesh 30 ) of Clinoptilolite were introduced into 12 conical flasks, in which $500 \mathrm{ml}$ of ammonia solution concentrations of 50 to $1400 \mathrm{mg} / \mathrm{l}$ were added. The flasks were then shaken and mixed until equilibrium was reached in each flask. Samples were taken periodically each 30 minutes for measurement of aqueous-phase ammonia concentration. The amount of ammonia accumulated on the Clinoptilolite was calculated by the following equation as the difference between the amounts present in the initial ammonia solution and that remained in solution after equilibrium with the Clinoptilolite:

$Q=\frac{\left(C_{0}-C_{e}\right) V}{M}$

Where:

$Q(\mathrm{mg} / \mathrm{g})$ is the amount of ammonia adsorbed

$C_{0}(\mathrm{mg} / \mathrm{l})$ represents initial ammonia concentration

$C_{e}(\mathrm{mg} / \mathrm{l})$ represents equilibrium ammonia concentration

$V$ (l) is the volume of solution

$M(\mathrm{~g})$ is the mass of zeolite

After the runs, the equilibrium point for each concentration will be selected. The equilibrium removal of the ammonia ion considered can be mathematically expressed in terms of adsorption isotherms. At equilibrium, the distribution of ammonia between the resin phase and solution phase can be described by the Freundlich or the Langmuir isotherm (Weber, 1972):

$Q=K_{f} C_{e}^{1 / n}$

$Q=\frac{K_{L} C_{e}}{1+a C_{e}}$

Respectively, where:

$\left(K_{f}\right)$, and $(l / n)$ are indicative isotherm parameters of sorption capacity and intensity, respectively $\left(K_{L}\right)$ and $(a)$ are Langmuir model parameters.
These models are rearranged to the linear form by taking logarithms on both sides:

$$
\begin{gathered}
\log Q=\log K_{f}+n \log C_{e} \\
\frac{C_{e}}{Q}=\frac{1}{K_{L}}+\left(\frac{a}{K_{L}}\right) C_{e}
\end{gathered}
$$

3) In the third phase of runs, the cation selectivity of zeolite for ammonia to other cations was investigated. One liter of $1 \mathrm{M}$ ammonia chloride solution was contacted with 1 gram of conditioned sample with mesh 30 . After mixing for 24 hours ammonia in solution were measured with Nessler method and the ammonia adsorbed in solid phase in equilibrium condition was determined. Simultaneously the ammonia equilibrium concentration with addition of $1 \mathrm{M}$ of $\mathrm{Ca}, \mathrm{Mg}$ and $\mathrm{K}$ salts to sample in a separate stage was determined. Then the binary separation factor is defined as the ratio of the distribution of ion A between the solution and zeolite phases and the distribution of ion $\mathrm{B}$ between these two phases:

$\alpha_{B}^{A}=\frac{q_{A} / C_{A}}{q_{B} / C_{B}}$

Where $q_{A}$ is the amount of ion A adsorbed to the zeolite (meq/g Clinoptilolite), $C_{A}$ the concentration of ion $\mathrm{A}$ in solution (meq/l), $q_{B}$ the amount of ion $\mathrm{B}$ adsorbed to zeolite (meq/g Clinoptilolite), and $C_{B}$ the concentration of ion B in solution (meq/l). The separation factors between $\mathrm{K}, \mathrm{Ca}, \mathrm{Mg}$ and $\mathrm{Na}$ to $\mathrm{NH}_{4}$ were determined using the method described by Clifford (1990).

\section{Column studies}

In the column studies, operational and regeneration parameters and ion-exchange capacity of Clinoptilolite were investigated.

Thus 30 grams of conditioned zeolite in three mesh sizes 20, 30 and 40 were transferred to three glass columns having $1 \mathrm{~cm}$ internal diameter by $60 \mathrm{~cm}$ length. A peristaltic pump was used and employed to feed the ammonia chloride solution $100 \mathrm{mg} / \mathrm{l}$ 
Table 2: Clinoptilolite capacity measurements recorded as $\mathrm{mg}$ of $\mathrm{NH}_{4}{ }^{+}$per gram of dry Clinoptilolite in batch system

\begin{tabular}{|cccccccc|}
\hline \multirow{2}{*}{$\begin{array}{c}\text { Test } \\
\text { No. }\end{array}$} & $\mathrm{M}$ & \multicolumn{2}{c}{ Mesh 20 } & \multicolumn{2}{c|}{ Mesh 30 } & \multicolumn{2}{c|}{ Mesh 40 } \\
\cline { 3 - 8 } & & $\mathrm{C}_{\mathrm{e}}$ & $Q$ & $\mathrm{C}_{\mathrm{e}}$ & $Q$ & $\mathrm{C}_{\mathrm{e}}$ & $Q$ \\
\hline 1 & 0 & 1000 & - & 1000 & - & 1000 & - \\
\hline 2 & 10 & 750 & 12.5 & 730 & 13.5 & 680 & 16 \\
\hline 3 & 20 & 550 & 11.25 & 500 & 12.5 & 480 & 13 \\
\hline 4 & 30 & 460 & 9.0 & 385 & 10.25 & 370 & 10.5 \\
\hline 5 & 40 & 380 & 7.75 & 320 & 8.5 & 210 & 9.88 \\
\hline 6 & 50 & 220 & 7.8 & 225 & 7.75 & 130 & 8.7 \\
\hline 7 & 60 & 160 & 7.0 & 202 & 6.65 & 105 & 7.46 \\
\hline
\end{tabular}

to the ion exchange column at the desired flow rate respectively. The ammonia concentration of the samples collected from the column exit was monitored. The breakthrough curve so obtained was used to calculate the capacity of the zeolite for ammonia exchange. The basic experimental setup is shown in Figure 1.

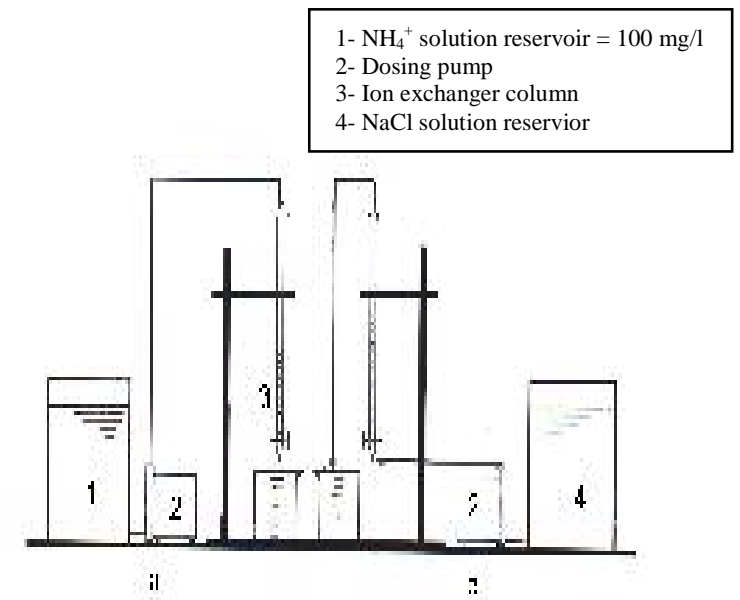

Figure 1: Schematic description of the process (a-Ion Exchange phase, $b$ - Regeneration phase)

For determination of the effect of the velocity on the ion exchange, three columns with 30 grams conditioned zeolite and mesh sizes of 20, 30 and 40 were used. The zeolite columns were exhausted by down flow at three different superficial velocities of 5, 10 and 15bed volume per hour (BV/h), until an ammonia breakthrough of more than $2 \mathrm{mg} / \mathrm{N} \mathrm{NH}_{4}{ }^{+}-\mathrm{N}$ was achieved. The columns were then regenerated with three different $\mathrm{NaCl}$ solutions $(0.3,0.5$ and $1 \mathrm{M} \mathrm{NaCl}$ ) and at $10 \mathrm{BV} / \mathrm{h}$. The regeneration was passed through the column in the up flow mode. The absence of ammonia in the effluent indicated the completion of regeneration. Another loading cycle was then carried out.

\section{Results \\ Batch studies}

1) The cation exchange capacity (CEC) of the Semnan Clinoptilolite was determined from the batch system. Three measurements of the zeolite capacity were made for three different mesh sizes: 20, 30 and 40 mesh. The same preconditioning treatment and the same technique for measuring capacity was used for each mesh size, and the results obtained are tabulated in Table 2.

The tests results showed that average ion exchange capacity for particles with 20, 30 and 40 mesh were between 6.65 to $16 \mathrm{mg} \mathrm{NH}_{4}{ }^{+} / \mathrm{g}$ zeolite weight. Furthermore the results showed that the rate of ion exchange has reverse relationship with the particle size. Thus the use of small particles increases the efficiency of processes.

2) For determination of adsorption isotherms, the results obtained by using Equation (2) are plotted vs. time and shown in Figure 2. The equilibrium points for each concentration are then selected.

The equilibrium removal of the ammonia ion considered can be mathematically expressed in terms of adsorption isotherms. Plotting the experimental data using Equations (5) and (6) in Figures 3 and 4 indicates that both models give good fit for the data. 


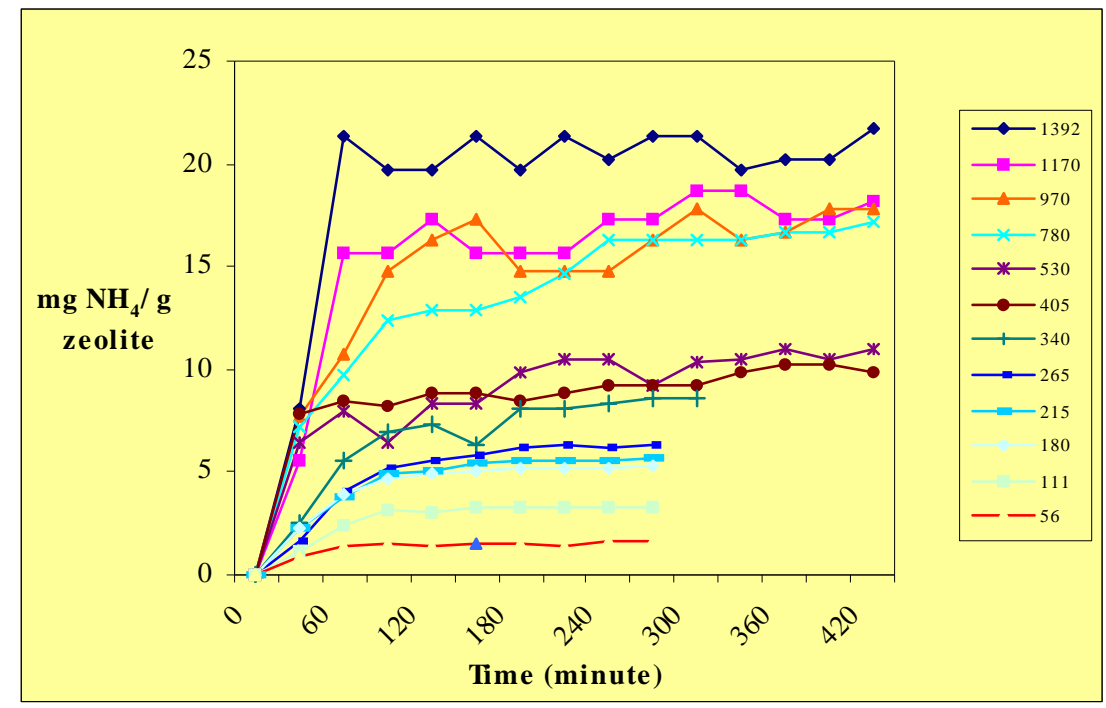

Figure 2: Effect of initial ammonia concentration in the aqueous solution on the exchange capacity

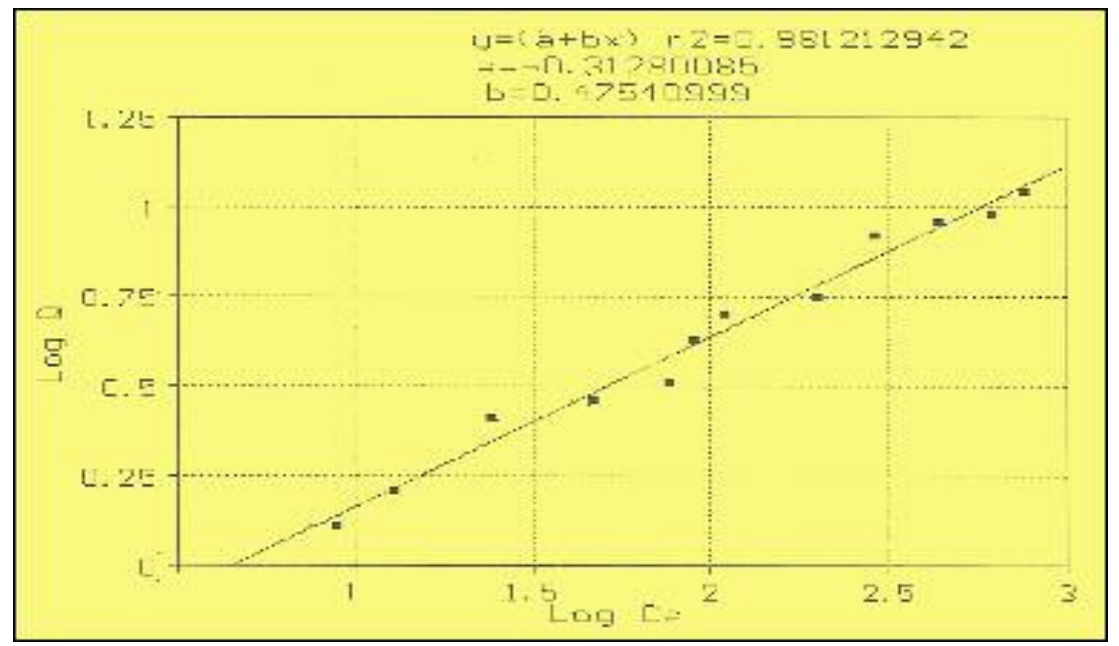

Figure 3: Linearised Freundlich isotherm for ammonia removal by zeolite

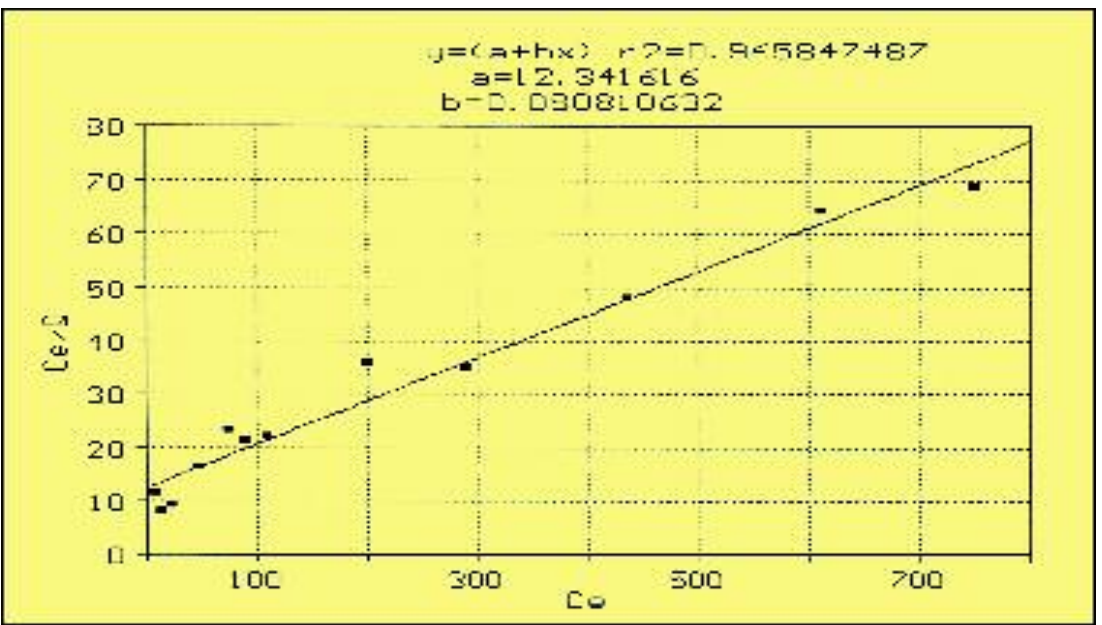

Figure 4: Linearised Langmuir isotherm for ammonia removal by zeolite 
Table 3: Langmuir and Freundlich models parameters for best fit and corresponding correlation coefficients

\begin{tabular}{|ccc|}
\hline \multirow{3}{*}{ Freundlich model } & $\mathrm{K}_{\mathrm{f}}$ & 0.49 \\
\cline { 2 - 3 } & $\mathrm{1/n}$ & 0.475 \\
\cline { 2 - 3 } & $\mathrm{R}^{2}$ & 0.981 \\
\hline \multirow{3}{*}{ Langmuir model } & $\mathrm{K}_{\mathrm{L}}$ & 0.081 \\
\cline { 2 - 3 } & $\mathrm{a}$ & 0.007 \\
\cline { 2 - 3 } & $\mathrm{R}^{2}$ & 0.966 \\
\hline
\end{tabular}

The values of $K_{L}, a, K_{f}$ and $1 / n$ that best fitted the data as well as the corresponding correlation coefficients are presented in Table 3. As a consequence, the Freundlich and Langmuir isotherms for ammonia removal can be represented by the following empirical equations 8 and 9 respectively:

$$
\begin{aligned}
Q & =0.49 C_{e}^{0.475} \\
& \text { and } \\
Q & =\frac{0.081 C_{e}}{1+0.007 C_{e}}
\end{aligned}
$$

The separation factors between $\mathrm{K}, \mathrm{Ca}, \mathrm{Mg}$ and $\mathrm{Na}$ to $\mathrm{NH}_{4}{ }^{+}$were determined by using equation (7). The binary separation factors were then obtained:

$\alpha_{N_{4} H_{4}}^{N H_{4}}=1, \alpha_{C a}^{N H_{4}}=4.71, \alpha_{M g}^{N H_{4}}=8.17$,

$\alpha_{N a}^{N H_{4}}=2.3, \alpha_{K}^{N H_{4}}=0.85$

\section{Column studies}

In continuous system, total cation exchange and till breakthrough point capacity obtained 17.31 to 18.98 and 9.61 to $11.17 \mathrm{mg} \mathrm{NH}_{4}{ }^{+} / \mathrm{g}$ zeolite weight. The results indicated that high level of regeneration (95-98\%) might be achieved with solution of $\mathrm{NaCl}$ (Table 4).

The concentrations of the solution for column studies were prepared synthetically at the level of $100 \mathrm{mg} / \mathrm{l}$ of $\mathrm{NH}_{4}^{+}$. The breakthrough curves of ammonia removal by Clinoptilolite and for various velocities $(5,10$, $15 \mathrm{BV} / \mathrm{hr}$.) of the aqueous solution are shown in Figure 5 and 6 respectively. Changing the flow rate from 5 to 10 and $15 \mathrm{BV} / \mathrm{h}$ resulted has no significant decrease in ammonia adsorption capacity (Figure 6).

\section{Regeneration}

Columns were prepared by complete regeneration with $0.3,0.5$ and $1 \mathrm{M} \mathrm{NaCl}$. Ammonia elution by regenerate solutions is shown in Figure 7. It is concluded that a volume of 3.5 liter $1 \mathrm{M} \mathrm{NaCl}$ solution is sufficient for nearly complete regeneration of the zeolite column. In lower concentration of regenerate solution for complete regeneration of column, more volumes of regenerate solution must be passed through the ion exchanger bed. The results indicated that high level of regeneration (95-98\%) might be achieved with solution of $\mathrm{NaCl}$.

\section{Discussion and Conclusion}

In this study, Semnan Clinoptilolite samples were tested in batch and continuous systems to evaluate their ability to adsorb ammonia from aqueous solutions. The removal of ammonia from synthetic solution was demonstrated successfully on a laboratory scale with a selective ion-exchange process.

The results from batch studies showed that the average of ion exchange capacity for samples have reverse relationship with the particle size and the use of small particles increases the efficiency of processes.

The data obtained from tests were applied to Langmuir and Freundlich isotherms. The Freundlich isotherm gives an adequate correlation coefficient value compared to the other.

Table 4: Clinoptilolite capacity measurements recorded as $\mathrm{mg}$ of $\mathrm{NH}_{4}{ }^{+}$per gram of dry Clinoptilolite in continuous system

\begin{tabular}{|cccccccc|}
\hline $\begin{array}{l}\text { Test } \\
\text { No. }\end{array}$ & $\begin{array}{c}\text { Zeolite } \\
\text { weight } \\
(\mathrm{g})\end{array}$ & $\begin{array}{c}\text { Particle } \\
\text { size } \\
(\mathrm{Mesh})\end{array}$ & $\begin{array}{c}\mathrm{NH}_{4}{ }^{+}, \mathrm{C}_{0} \\
(\mathrm{mg} / \mathrm{l} .)\end{array}$ & $\begin{array}{c}\text { Breakthrough } \\
\text { Capacity } \\
(\mathrm{mg} / \mathrm{g})\end{array}$ & $\begin{array}{c}\text { Total } \\
\text { capacity } \\
(\mathrm{mg} / \mathrm{g})\end{array}$ & $\begin{array}{c}\text { Total } \mathrm{NH}_{4}{ }^{+} \\
\text {adsorbed in } \\
\text { column }(\mathrm{mg})\end{array}$ & $\begin{array}{c}\text { Total } \mathrm{NH}_{4}{ }^{+} \\
\text {regeneration }(\mathrm{mg})\end{array}$ \\
\hline 1 & 30 & 20 & 101 & 9.61 & 17.31 & 519.3 & 507.63 \\
\hline 2 & 30 & 30 & 101 & 10.06 & 18.38 & 551.4 & 539.37 \\
\hline 3 & 30 & 40 & 101 & 11.17 & 18.98 & 569.4 & 558.37 \\
\hline
\end{tabular}




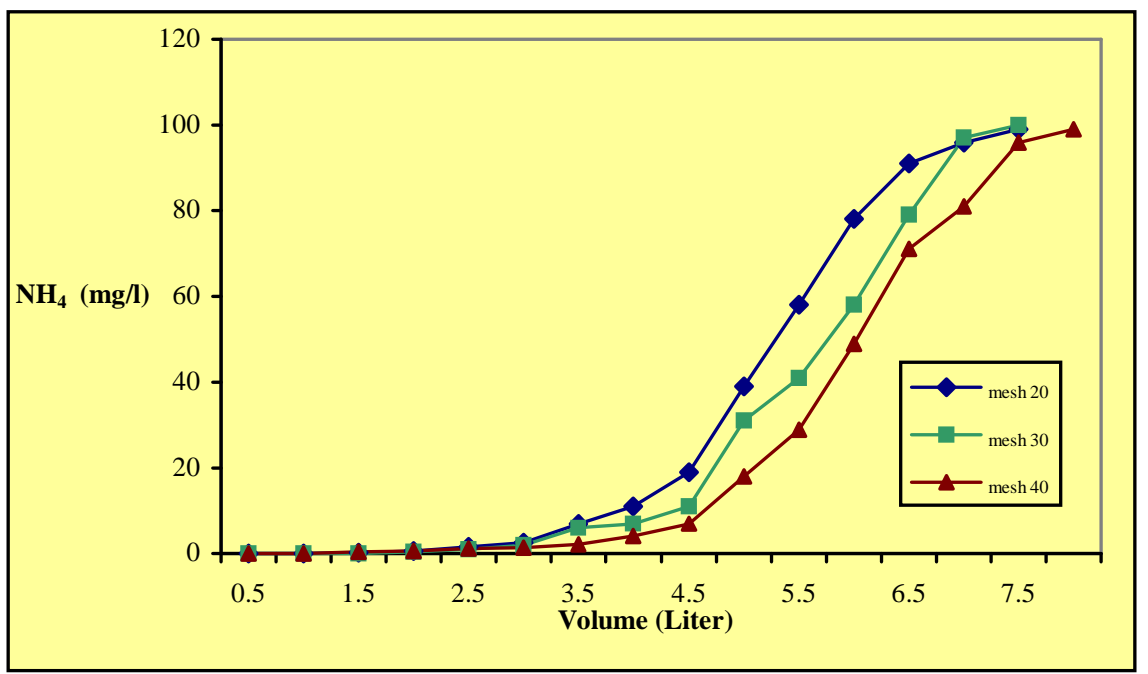

Figure 5: Clinoptilolite capacity measurements recorded as $\mathrm{mg}$ of $\mathrm{NH}_{4}{ }^{+}$ per gram of dry Clinoptilolite in continuous system

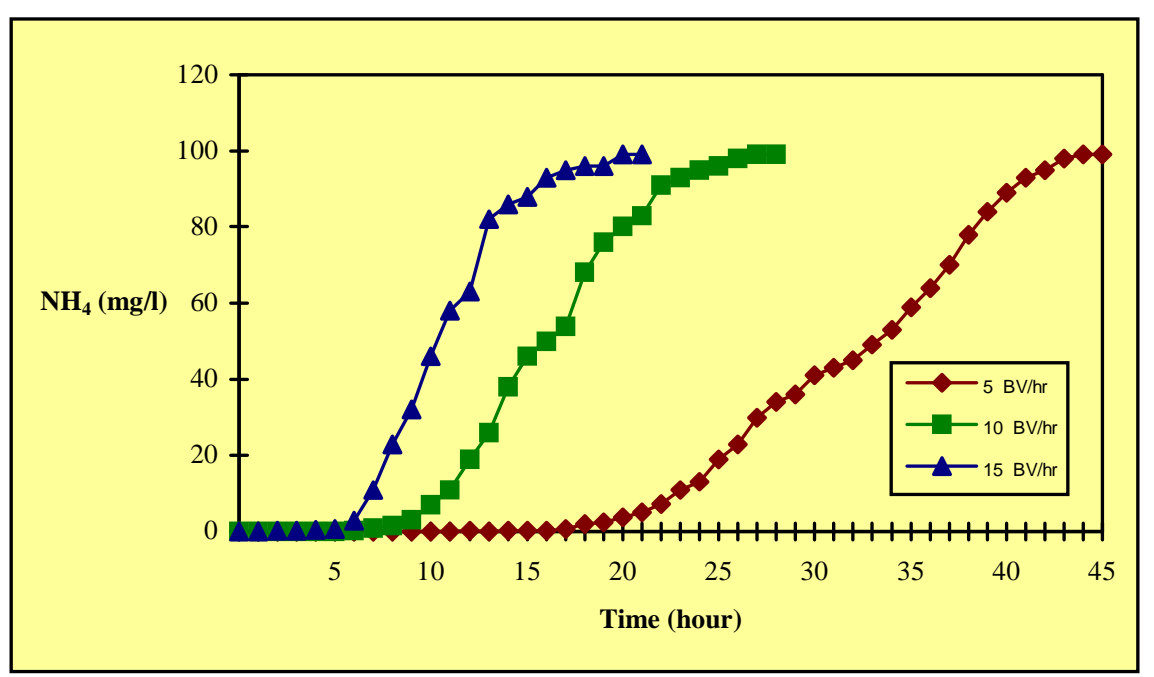

Figure 6: Effect of the velocity on the breakthrough curve of $\mathrm{NH}_{4}{ }^{+}$ removal at $100 \mathrm{mg} / \mathrm{l}$ initial ammonia concentration

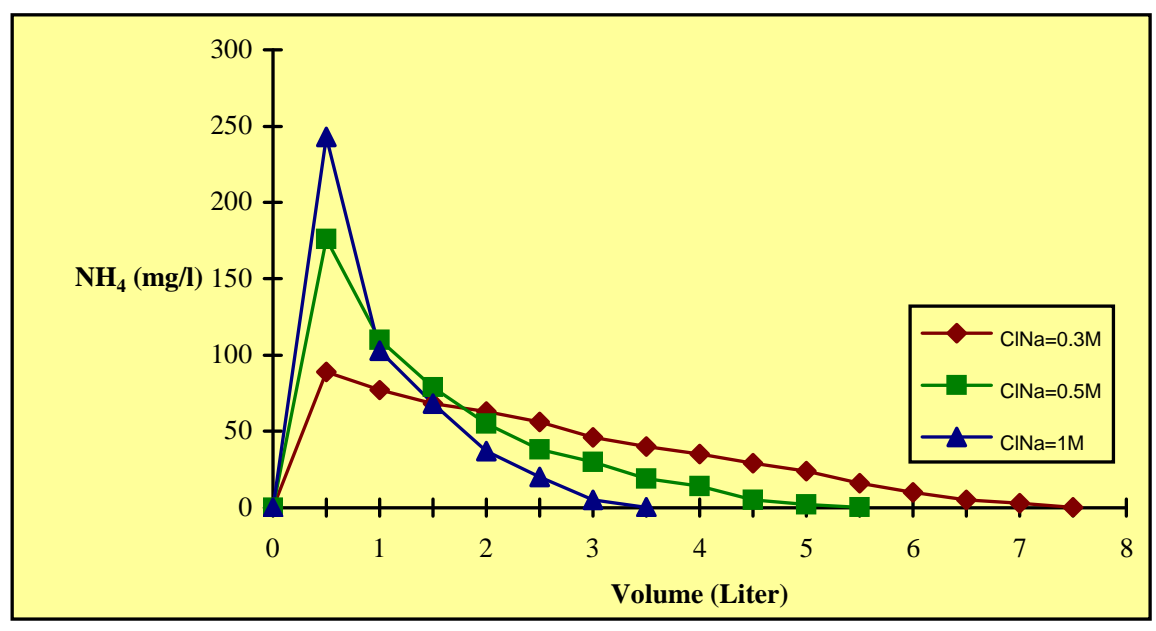

Figure 7:Ammonia elution by regenerate solutions in column system 
So the results obtained from the cation selectivity of zeolite present high selectivity of the Clinoptilolite toward $\mathrm{K}^{+}$and $\mathrm{NH}_{4}{ }^{+}$while much lower selectivity towards $\mathrm{Na}^{+}, \mathrm{Ca}^{2+}$ and $\mathrm{Mg}^{2+}$. Based on the separation factors results, the following Clinoptilolite affinity order can be written:

$$
\mathrm{K}^{+}>\mathrm{NH}_{4}^{+}>\mathrm{Na}^{+}>\mathrm{Ca}^{2+}>\mathrm{Mg}^{2+}
$$

The results obtained from column studies showed that the total exchange capacity of the Semnan Clinoptilolite for three different mesh sizes were determined between 17.31 to 18.98 mg $\mathrm{NH}_{4}{ }^{+} / \mathrm{g}$ of dry Clinoptilolite weight. The zeolite particles with mesh 40 gives a higher ammonia adsorption capacity than that the others. The adsorption capacities calculated by graphical integration of the area above the breakthrough curves are about 0.96, 1.02 and $1.05 \mathrm{meq} / \mathrm{g} \mathrm{NH}_{4}{ }^{+}$for particle sizes ranging between 0.42 to $0.84 \mathrm{~mm}$, respectively. This indicates that the smaller particle size has a higher ion-exchange capacity due to greater available surface area. The capacity to $2 \mathrm{mg} / \mathrm{l}$ $\mathrm{NH}_{4}{ }^{+}$breakthrough was reached in 93, 87 and $83 \mathrm{BV}$ for the samples column with velocities of 5,10 and $15 \mathrm{BV} / \mathrm{h}$. respectively. As the velocity of the aqueous solution decreases, the hydraulic residence time increases, resulting in more $\mathrm{NH}_{4}^{+}$being removed by the ionexchange resin. These are reasonable velocities and have no negative effect on adsorption capacity. The column regeneration phase carried out with $10 \mathrm{BV} / \mathrm{h}$ showed that in lower concentration of regenerate solution for complete regeneration of column, more volumes of regenerate solution must be passed through the ion exchanger bed. The results indicated that high level of regeneration (95$98 \%$ ) might be achieved with solution of $\mathrm{NaCl}$. Three loading and three regeneration cycles were carried out without loss of $\mathrm{NH}_{4}{ }^{+}$ adsorption capacity. This shows that on regeneration of the zeolite column with $\mathrm{NaCl}$ solution, the $\mathrm{Na}$ ions have activated the zeolite column. After the 2nd and 3rd regenerations, the loading process was repeated and it was found that the ammonia adsorption capacity of the Clinoptilolite remained constant. This indicates that using $\mathrm{NaCl}$ solution, the regeneration of the column could be done repeatedly without loss of ammonia adsorption capacity.
Results of the experimental investigation are used to develop optimum operational conditions for Clinoptilolite exchangers. Now days, the most wastewater treatment plants in Iran are designed only for removal of organic matter and ammonia remain in effluent. The use of ion exchange with Clinoptilolite can be lead to an economical removal of $\mathrm{NH}_{4}{ }^{+}$from wastewater effluent.

\section{Acknowledgments}

The authors would like to express their appreciation and thanks to the Department of Environmental Engineering, School of Public Health and Institute of Health Research Center, Tehran University of Medical Sciences for the valuable financial support. The great thanks also forwarded to Mr. H. Ehsani for his close Cooperation during the study.

\section{References}

Ames, L. L., zeolite removal of ammonium ions from agriculture wastewater. Proc. $13^{\text {th }}$ Pacific North West Indus. Waste Conf., Washington University, 52-135, 1967

AWWA, Water quality and treatment. Mc Graw Hill Co., New York, 1990

Clifford D. A., Ion exchange and inorganic adsorption, in water quality and treatment. McGraw-Hill, AWWA, Washington D.C., 1990

Culp, H. L., G. M. Wesner, and G. L. Culp, Handbook of advanced wastewater treatment. $2^{\text {nd. }}$ Ed., Van Nostrand Reinhold Co., New York, 1978

EPA, Process design manual for nitrogen control. U.S.EPA, Technology Transfer, 1975

Ershov A. V., Use of transcarpathin clinoptilotic rock to remove ammonium nitrogen from municipal sewage. Khim Technol, Vody, (6): 7175, 1984

Gaspard, M., A. Neveu and G. Martin, Clinoptilolite in drinking water treatment for $\mathrm{NH}_{4}{ }^{+}$removal. Water Res., 17 (3): 279-288, 1983

Haralambous A., E. Maliou and M., Malamis, The use of zeolite for ammonium uptake. Water Sci. Technol., 25 (1): 139-145, 1992

Kazemian H., Chemical analysis, Characterization, and determination of Ion-Exchange properties of an Iranian Natural zeolite. M. S. thesis, Department of Chemistry, School of Sciences, University of Isfahan, Iran, 1993 
Koon J. H., and W. J. Kaufman, Ammonium removal from municipal wastewaters by ion exchange. J. WPCF 47 (3): 448-465, 1975

Liberti L., Nutrient removal and recovery by ion exchange. J. Water Res. 15: 337-342, 1981

Mercer, B. W., L. L. Ames, J. C. Touhill, W. J. Van Slyke and R. B. Dean, Ammonium removal from secondary effluents by selective ion-exchange. J. WPCF. 42 (2): R95-R107, 1970

Metcalf and Eddy, Wastewater Engineering: Treatment and Reuse. $4^{\text {th. }}$ Ed., Mc Graw Hill Co., New York, 2003

Schoeman J. J., Evaluation of a South African Clinoptilolite for ammonium-nitrogen removal from an underground mine water. Water SA., 12 (2): 73-82, 1986

Singh G. and B. Prasad, Removal of ammonium from coke plant wastewater by using synthetic zeolite. Water Environ. Res., 69 (2): 157-161, 1997

Standard Methods for the Examination of Water and Wastewater $18^{\text {th. }}$ Ed., American Public Health Association, NW. DC., 1992

Weber W. J., Physicochemical processes for water quality control. Wiley Interscience, 9: 261-304, 1972 
